\title{
UJI KUALITAS BUBUK CABAI RAWIT (Capsicum frutescens) BERDASARKAN BERAT TUMPUKAN DAN LAMA PENGERINGAN MENGGUNAKAN CABINET DRYER
}

\section{TEST QUALITY OF CAYENNE PEPPER (Capsicum frutescens) POWDER BASED ON STACK WEIGHT AND LONG DRYING USING CABINET DRYER}

\author{
Maryam Jamilah'), Kadirman²), Ratnawaty Fadilah') \\ 1Alumni Program Studi Pendidikan Teknologi Pertanian FT UNM \\ ${ }^{2}$ Dosen ${ }^{3}$ Fakultas Teknik FT UNM \\ Maryam_0973@yahoo.com
}

\begin{abstract}
This study aims to determine the effect of stack weight and drying time on the quality of cayenne pepper (Capsicum frutescens) powder. This study used a completely randomized design (CDR) factorial with treatment of stack weight $(1 \mathrm{~kg}, 2 \mathrm{~kg}$ and $3 \mathrm{~kg}$ ) and drying time (14 hours, 18 hours and 22 hours). Test parameters consist of yield, moisture content, and organoleptic test. The data analysis technique of this study uses analysis of variance (ANOVA), if it shows a significant difference followed by Duncan's advanced test of $5 \%$. Based on the results of chemical test research, the treatment of $3 \mathrm{~kg}$ stack weight with 14 hours drying time has the highest yield and moisture content. Organoleptic test results for the highest distinctive taste were in the treatment of $2 \mathrm{~kg}$ stack weight with 18 hour drying time, while the results of organoleptic test for the highest characteristic odor were in the treatment of $1 \mathrm{~kg}$ stack weight with 14 hours drying time.
\end{abstract}

Keywords: Cayenne pepper powder, cabinet dryer, stack weight and drying time

\section{PENDAHULUAN}

Cabai (Capsicum) berasal dari Amerika Tengah dan saat ini merupakan komoditas penting dalam kehidupan masyarakat di Indonesia.Hampir semua rumah tangga mengkonsumsi cabai setiap hari sebagai pelengkap dalam hidangan keluarga sehari-hari. Konsumsi cabai ratarata di Indonesia sebesar 4,6 kg per kapita per tahun (Direktorat Pengolahan Hasil Pertanian, 2009).

Secara umum, cabai terdiri dari dua jenis, yaitu cabai besar dan cabai kecil. Cabai besar biasanya memiliki rasa yang tidak terlalu pedas, berukuran besar, dan banyak digunakan sebagai hiasan kuliner yang termasuk cabai jenis ini adalah cabai besar dan cabai manis atau cabai paprika (Capsicum annum). Cabai jenis ini biasanya dikenal dengan sebutan pepper. Cabai pedas adalah cabai yang terkenal dengan sebutan chili. Cabai jenis inilah yang disukai di Indonesia, contohnya cabai rawit (Capsicum frutescens) (Suriana, 2012).

Produktivitas cabai tergantung dari musim sehingga produksinya tidak merata sepanjang tahun, yakni berkurang dimusim hujan menyebabkan harga tinggi dan berlebihan di musim kering/kemarau mengakibatkan harga cabai jatuh (Iswari dan Srimaryanti, 2004). Pada musim kemarau produksi cabai melimpah sehingga kadang masih ada cabai yang belum terjual juga, jadi cabai tersebut menjadi busuk serta mendatangkan kerugian. Penyebab dari cabai yang cepat membusuk adalah cabai mengalami proses kehidupan yaitu proses pernafasan yang secara alami tidak dihentikan, mudah mengalami perubahan 
metabolisme karena kandungan airnya yang tinggi, sehingga tidak dapat lama disimpan dalam bentuk segar (Hartuti dan Sinaga, 1997). Oleh karena itu perlu dilakukan upaya untuk memperpanjang umur simpannya melalui upaya pengolahan, seperti cabai kering, bubuk cabai, saus cabai, dll (Direktorat Pengolahan Hasil Pertanian, 2009).

Tujuan dari pengeringan adalah mengurangi kadar air bahan sampai batas dimana mikroorganisme dan kegiatan enzim yang dapat menyebabkan pembusukan akan terhenti, dengan demikian bahan yang dikeringkan dapat mempunyai waktu simpan yang lama. Disamping itu juga pengolahan dapat digunakan untuk meningkatkan nilai tambah (added value) suatu produk (Yuarni, dkk, 2015).

Bubuk cabai adalah bahan pangan yang dibuat dari cabai kering yang dihaluskan/dikeringkan. Bubuk cabai sering digunakan sebagai bumbu siap pakai dan bahan tambahan dalam industri makanan (Direktorat Pengolahan Hasil Pertanian, 2009). Bentuk bubuk dianggap mempunyai nilai ekonomis tinggi, praktis dalam penggunaan serta memudahkan pengemasan dan pengangkutannya (Hambali dkk, 2005). Bahkan di Korea cabai kering dan cabai bubuk sudah banyak dikonsumsi sebagai bahan masakan dan juga dibeberapa negara lainnya seperti Jepang, Hongkong, Taiwan dan Malaysia pun sudah mulai membudayakan cabai kering untuk bahan memasak (Anonima, 2011)

Kualitas bubuk cabai sangat ditentukan oleh proses pembuatannya, seperti cara sortasi, blanching, pengeringan, pengemasan dan penyimpanan (Direktorat Pengolahan Hasil Pertanian, 2009). Proses terpenting dari pembuatan bubuk cabai adalah pengeringan. Ada dua macam pengeringan yaitu tradisional dan modern. Pengeringan tradisional yang dilakukan hingga saat ini oleh masyarakat yaitu dengan menjemur cabai rawit (Capsicum frutescen) atau hanya mengangin-anginkan saja hingga kering, sedangkan pengeringan secara modern yaitu dengan menggunakan alat atau mesin pengering salah satunya adalah mesin cabinet dryer.(Kartasapoetra, 1994).Cabinet dryer merupakan pengering mekanis yang memanfaatkan penguapan energi panas.Kelebihan dari alat pengering ini adalah pengeringan menggunakan cabinet dryer tidak membutuhkan waktu yang lama karena suhu yang digunakan dapat dikontrol sesuai dengan sifat fisik bahan (Ardianto, dkk., 2016). Pengeringan ini memerlukan energi untuk memanaskan alat pengering, mengimbangi radiasi panas yang keluar dari alat, memanskan bahan, menguapkan air bahan serta menggerakkan udara (Kartasapoetra, 1994).

Berdasarkan penjelasan tersebut maka perlu diadakan penelitian tentang ujikadar cabai dilihat dari proses pengeringan berdasarkan berat tumpukan dan lama pengeringan.

\section{METODE PENELITIAN}

\section{Rancangan Penelitian}

Jenis penelitian ini adalah penelitian kuantitatif dengan pendekatan eksperimen, dalam penelitian ini terdapat variabel kontrol dan variabel eksperimen sebagai acuan antara keadaan awal dengan keadaan setelah diberi perlakuan rancangan percobaan yang digunakan dalam penelitian ini adalah Rancangan Acak Lengkap (RAL) Faktorial dengan variasi berat tumpukan (1 $\mathrm{kg}, 2 \mathrm{~kg}$ dan $3 \mathrm{~kg}$ ) dan variasi lama 
pengeringan (14 jam, 18 jam dan22 jam) termasuk kontrol (pengeringan sinar matahari selama 8 hari)setiap kombinasi perlakuan diulang sebanyak 3 kalii sehingga diperoleh 36 percobaan.

Penelitian ini bertujuan untuk mengetahui pengaruh lama pengeringan dan berat tumpukan terhadap kualitas cabai (Capsicum frutescens).

\section{Alat Penelitian}

Peralatan yang digunakan dalam penelitian ini dipilih kondisi yang baik, bersih dan kering sehingga siap untuk digunakan peralatan yang digunakan dalam eksperimen ini, yaitu wadah plastik/baskom, termometer, timbangan, gelas ukur, sendok, kompor, talang cabinet dryer berukuran 52 $\mathrm{cm} \times 48,5 \mathrm{~cm}$ x $2 \mathrm{~cm}$;cabinet dryer, blender, plastik zipper.

\section{Bahan Penelitian}

Bahan yang digunakan dalam pembuatanbubukcabai adalah cabai rawit (Capsicum frutescens) segar, larutan natrium metabisulfit $\left(\mathrm{Na}_{2} \mathrm{~S}_{2} \mathrm{O}_{5}\right)$ digunakan pada saat proses blanching, dan air.

\section{Pembuatan Bubuk Cabai Rawit}

Proses pembuatan bubuk cabai rawit, adalah:

a. Sortasi atau pemilihan cabai rawit (Capsicum frutescens).Sebelum cabai disortasi sebaiknya cabai dituang ke daam wadah plastik/baskom. Sortasi pemilihan dilakukan untuk memilih cabai rawit yang baik, yaitu cabai rawit yang harus berwarna merah dan orange, sehat dan fisiknya mulus (tidak cacat). Tangkai cabai dan bagian yang rusak harus dibuang.

b. Blanching. Proses blanching bertujuan untuk mencegah perkembangan bau dan warna yang tidak dikehendaki selama pengeringan dan penyimpanan. Blanching akan menyebabkan udara dalam jaringan keluar dan pergerakan air tidak terhambat sehingga proses pengeringan menjadi cepat (Anonimb 2012), dengan cara merendam cabai rawit (Capsicum frutescens) pada suhu $90^{\circ} \mathrm{C}$ sebanyak $1 \mathrm{~kg}$ cabe dibutuhkan \pm 1,5Ldan ditambahkannatrium metabisulfit $\left(\mathrm{Na}_{2} \mathrm{~S}_{2} \mathrm{O}_{5}\right)$ sebanyak $2 \mathrm{~g} / \mathrm{l}$ air selama \pm 6 menit. Banyaknya air yang digunakan diukur menggunakan gelas ukur serta natrium metabisulfit yang ditambahkan dalam air diukur menggunakan timbangan.

c. Setelah proses blanching, selanjutnya cabai ditiriskan dan dimasukkan ke dalam air dingin sampai proses pemanasan selesai, kemudian cabai ditaruh pada talang cabinet dryer.

d. Kemudian proses selanjutnya adalah cabai dikeringkan dalam cabinetdryer dengan perlakuan berat tumpukan $1 \mathrm{~kg}$, $2 \mathrm{~kg}$, dan $3 \mathrm{~kg}$ serta lama pengeringan sinar matahar selama8 hari (kontrol), 14 jam, 18 jam, dan 22 jam

e. Cabai yang sudah dikeringkan kemudian digiling menggunakan blender sampai menjadi bubuk. Setelah diblender bubuk cabai dipindahkan ke dalam wadah plastik/baskom menggunakan sendok

f. Setelah bubuk cabai mencapai tingkat kekeringan yang diinginkan, selanjutnya dapat segera dikemas untuk menghindari penyerapan kembali uap air menggunakan plastik zipper.

\section{Teknik Pengumpulan Data}

Teknik pengumpulan data yang dilakukan pada penelitian ini yaitu dengan melakukan uji rendemen, uji kadarair dan uji organoleptik terdiri dari rasa khas dan aroma/bau khas. 


\section{Teknik Analisis Data}

Teknik analisis yang digunakan untuk mengetahui pengaruh setiap variabel terhadap variabel yang akan diamati, maka analisis yang digunakan yaitu analisis sidik ragam yang diolah dengan menggunakan program SPSS (Versi 20). Jika analisis menunjukkan adanya pengaruh nyata maka dilanjutkan uji Duncan dengan taraf kepercayaan $95 \%$.

\section{HASIL DAN PEMBAHASAN}

\section{Rendemen}

Rendemen adalah perbandingan jumlah presentase produk yang didapatkan dari membandingkan berat awal produk dengan berat akhir.

Hasil analisis interaksi antar perlakuan berta tumpukan dan lama pengeringan rendemen bubuk cabai rawit dapat dilihat pada Gambar 1.

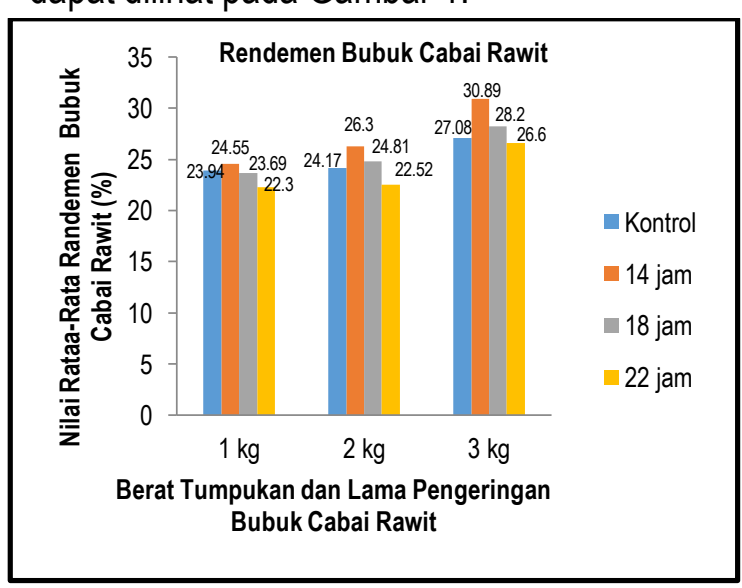

Gambar 1

\section{Hasil Rendemen Bubuk Cabai Rawit Selama Pengeringan}

Hasil analisis rendemenbubuk cabai rawit pada interaksi perlakuan berat tumpukan dan lama pengeringan (Gambar 1) memiliki nilai yang berbeda-beda. Perlakuan berat tumpukan dan lama pengeringan memberikan pengaruh yang berbeda sangat nyata terhadap kadar air bubuk cabai rawit yang dihasilkan. Rendemen tertinggi diperoleh pada berat tumpukan $3 \mathrm{~kg}$ dengan lama pengeringan 14 jam yaitu $30,89 \%$ dan kadar air terendah diperoleh pada perlakuan berat tumpukan 1 $\mathrm{kg}$ dengan lama pengeringan 22 jam yaitu $22,3 \%$. Analisis rata-rata kadar air menunjukkan bahwa semakin sedikit jumlah berat tumpukan, maka kadar airnya juga akan menurun.

Hal ini diperkuat dengan pernyataan Susinggih dkk. (2015) bahwa proses pengeringan menyebabkan kandungan air selama proses pengolahan berkurang, sehingga mengakibatkan penurunan rendemen. Hal ini diperkuat dengan pernyataan bahwa salah satu faktor yang mempengaruhi pengeringan adalah ukuran bahan dan lama pengeringan (Taufik, 2013).Salah satu dari penyebab perubahan pada ukuran bahan adalah berubahnya rendemen pada cabai yang telah dikeringkan.

\section{Kadar Air}

Kadar air suatu bahan panganmerupakan salah satu faktor yang dapatmenentukan tingkat keawetan selamapenyimpanan (Risnawati, dkk, 2017). Kadar airakan mempengaruhi pertumbuhanmikroorganisme, semakin tinggi kadar air maka semakin cepat tingkat kerusakan suatu bahan pangan tersebut (Dendang, dkk, 2016).

Hasil analisis interaksi perlakuan antara berat tumpukan dan lama pengeringan kadar air bubuk cabai rawit dapat dilihat pada Gambar 2. 


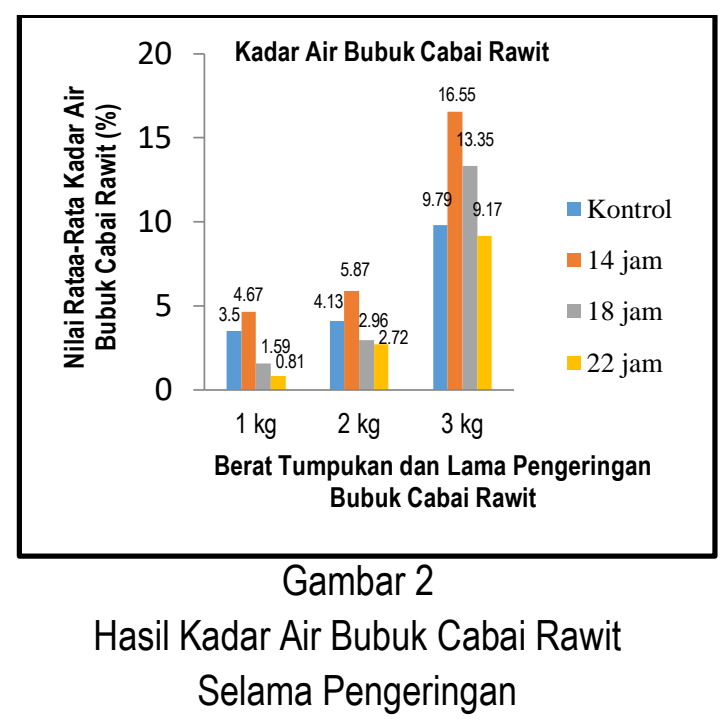

Hasil analisis kadar air bubuk cabai rawit pada interaksi perlakuan berat tumpukan dan lama pengeringan (Gambar 2) memiliki nilai yang berbeda-beda. Perlakuan berat tumpukan dan lama pengeringan memberikan pengaruh yang berbeda sangat nyata terhadap kadar air bubuk cabai rawit yang dihasilkan. Kadar air tertinggi diperoleh pada berat tumpukan 3 $\mathrm{kg}$ dengan lama pengeringan 14 jam yaitu $16,55 \%$ dan kadar air terendah diperoleh pada perlakuan berat tumpukan $1 \mathrm{~kg}$ dengan lama pengeringan 22 jam yaitu $0,81 \%$. Analisis rata-rata kadar air menunjukkan bahwa semakin sedikit jumlah berat tumpukan, maka kadar airnya juga akan menurun. Hal ini diperkuat oleh pendapat Fitriani (2008) bahwa semakin lama waktu pengeringan kadar air akan menurun, menyebabkan penguapan air lebih banyak sehingga kadar air dalam bahan semakin kecil. Hal yang sama juga dikemukakan oleh Totok dkk (2008) bahwa kemampuan bahan untuk melepaskan air dari permukaannya akan semakin besar dengan meningkatnya lama pengeringan yang digunakan sehingga kadar air yang dihasilkan semakin rendah. Di sisi lain, Dendang, dkk (2016) menyatakan bahwa kadar air bubuk cabaimengalami penurunan seiringdengan peningkatan lama dan suhu pengeringan. Penurunan kadar air disebabkan hilangnya sebagian air yangterkandung dalam cabai akibat pengeringan melalui penguapan menggunakan energi panas. Hal ini diperkuat dengan pernyataan bahwa salah satu faktor yang mempengaruhi pengeringan adalah ukuran bahan dan lama pengeringan (Taufik, 2013). Salah satu dari penyebab perubahan pada ukuran bahan adalah berubahnya rendemen pada cabai yang telah dikeringkan.

Capsaicin sangat rentan terhadap kondisi panas sehingga suhu dan lama pengeringan untuk mengurangi kadar air sangat berpengaruh terhadap kehilangan kandungan capsaicin pada cabai. Oleh karena itu pada pengeringan cabai digunakan suhu $60^{\circ} \mathrm{C}$ yang di anggap sebagai suhu optimal karena dapat meminimalisir kehilangan capsaicin pada cabai. Hal ini sesuai dengan pernyataan Suyanti (2007), bahwa suhu pengeringan yang digunakan untuk mengurangi kadar air cabai adalah $60^{\circ} \mathrm{C}$. Serta didukung oleh Yuliarti \& Christina (2001), bahwa pengeringan dengan suhu $50-65^{\circ} \mathrm{C}$ dapat mempertahankan kandungan capsaicin.

Untuk kualitas bubuk cabai menurut SNI 01-3389-1994 memiliki nilai kadar air maksimal $11 \%$. Hal ini berarti hanya bubuk cabai rawit dengan kombinasi perlakuan berat tumpukkan $3 \mathrm{~kg}$ dengan lama pengeringan 22 jam yang dihasilkan dengan kadar air rata-rata, yaitu 16,55\% dan $3 \mathrm{~kg}$ dengan lama pengeringan 18 jam yang dihasilkan dengan kadar air rata-rata, yaitu $13,35 \%$ yang tidak memenuhi syarat mutu bubuk cabai. Suprapti dan Lies (2003) mengemukakan bahwa kadar air sangat berpengaruh terhadap mutu bahan pangan sehingga dalam proses pengolahan dan 
penyimpanan bahan pangan, air perlu dikeluarkan, salah satunya dengan cara pengeringan. Penetapan kadar air bertujuan untuk mengetahui batasan maksimal atau rentang tentang besarnya kandungan air di dalam bahan.

\section{Rasa Khas}

Rasa merupakan salah satu atribut mutu yang menentukan dalam penerimaan konsumen terhadap suatu produk. Rasa dapat diperoleh dengan penambahan bahan tambahan seperti bumbu ataupun dari bahan baku produk itu sendiri maupun dari proses pengolahan yang digunakan (Jusniati, dkk, 2017).

Hasil analisis interaksi antar perlakuan berat tumpukan dan lama pengeringan uji organoleptik terhadap aroma/bau khas bubuk cabai dapat dilihat pada Gambar 3.

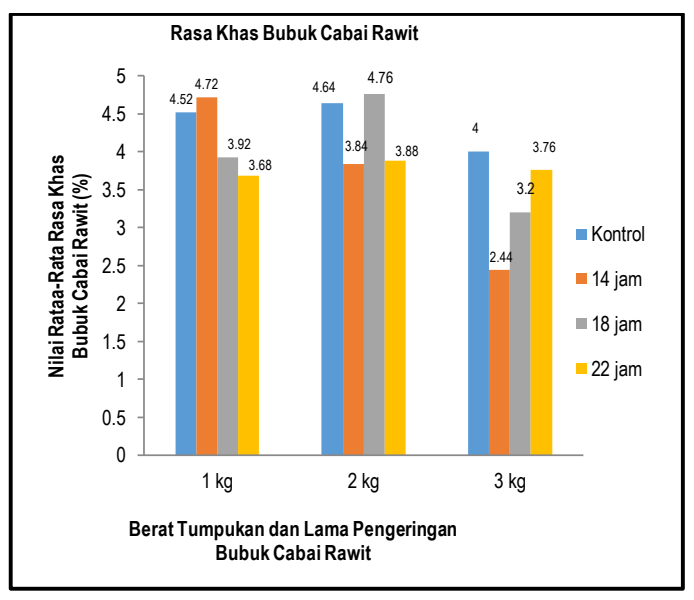

Gambar 3

Hasil Uji Organoleptik Rasa Khas

Bubuk Cabai Rawit

Hasil pengamatan uji organoleptik pada rasa khas bubuk cabai rawit pada interaksi perlakuan berat tumpukan dan lama pengeringan (Gambar 3) memiliki nilai yang berbeda-beda. Perlakuan berat tumpukan dan lama pengeringan memberikan pengaruh yang berbeda sangat nyata terhadap kadar rasa khas bubuk cabai rawit yang dihasilkan. Nilai rata-rata uji organoleptik pada rasa khas tertinggi diperoleh pada berat tumpukan $2 \mathrm{~kg}$ dengan lama pengeringan 18 jam yaitu 4,76 yang artinya "sangat khas". Hal ini disebabkan karena rasa khas bubuk cabai rawit yang diperoleh sangat kuat, sehingga lebih disukai oleh panelis.Sesuai dengan pernyataan Setiawati dan Winneke (2016), mengemukakan cabai kering rasanya lebih kuat dibandingkan dengan cabai yang segar. Hal ini dperkuat dengan pernyataan Asni dan Kiki (2017), mengemukakan cabai yang telah kering mempunyai bau dan rasa khas yang kuat.

Nilai rata-rata uji organoleptik pada rasa khas terendah diperoleh pada perlakuan berat tumpukan $3 \mathrm{~kg}$ dengan lama pengeringan 14 jam yaitu 2,44 yang artinya "tidak khas". Hal ini disebabkan karena rasa khas bubuk cabai yang diperoleh tidak kuat, sehinggan tidak disukai oleh panelis.Cabai mengandung oleoresin yang menimbulkan aroma yang khas. Oleoresin adalah suatu produk yang mengandung resin, minyak-minyak esensial yang bersifat volatil dan bahan aktif lainnya yang diekstrak dengan pelarut non-aqueous seperti hidrokarbon (Furia, 1980).

Berdasarkan kualitas bubuk cabai menurut SNI 01-3389-1994 harus memiliki rasa yang khas. Hal ini berarti bubuk cabai yang sesuai standar SNI melalui penilaian uji oganoleptik adalah dengan kombinasi perlakuan berat tumpukkan $1 \mathrm{~kg}$ dengan pengeringan menggunakan sinar matahari (kontrol) dengan rata-rata, yaitu 4,52 (sangat khas); berat tumpukkan $1 \mathrm{~kg}$ dengan lama pengeringan 14 jam yang dihasilkan dengan rata-rata, yaitu 4,72 (sangat khas); berat tumpukan $2 \mathrm{~kg}$ dengan 
pengeringan menggunakan sinar matahari (kontrol), yaitu 4,64; berat tumpukan $2 \mathrm{~kg}$ dengan lama pengeringan 18 jam, yaitu 4,76 (khas); dan berat tumpukan $3 \mathrm{~kg}$ dengan pengeringan menggunakan sinar matahari (kontrol) yang dihasilkan dengan rata-rata, yaitu 4 (khas).

\section{Aroma/Bau Khas}

Aroma mempunyai peranan yang sangat penting dalam penentuan derajat penilaian dan kualitas suatu bahan pangan. Selain bentuk dan warna, bau atau aroma akan berpengaruh dan menjadi perhatian utama. Sesudah bau diterima maka penentuan selanjutnya adalah citarasa disamping teksturnya (Rubianty dan Kaseger, 1985).

Hasil analisis interaksi antar perlakuan berat tumpukan dan lama pengeringan uji organoleptik terhadap aroma/bau khas bubuk cabai dapat dilihat pada Gambar 4.

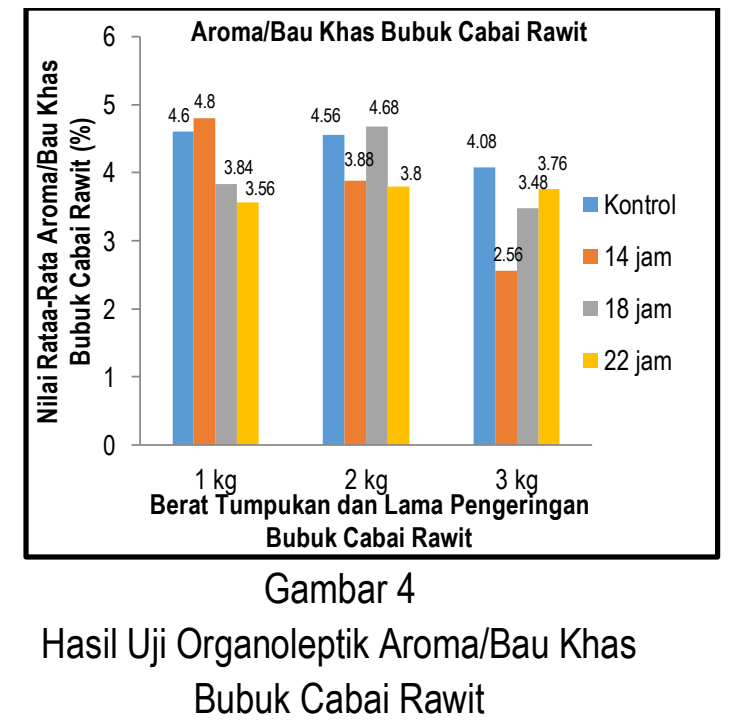

Hasil pengamatan uji organoleptik pada aroma/bau khas bubuk cabai rawit pada interaksi perlakuan berat tumpukan dan lama pengeringan (Gambar 4.4) memiliki nilai yang berbeda-beda. Perlakuan berat tumpukan dan lama pengeringan memberikan pengaruh yang berbeda sangat nyata terhadap kadar aroma/bau khas bubuk cabai rawit yang dihasilkan. Nilai ratarata uji organoleptik pada aroma/bau khas tertinggi diperoleh pada berat tumpukan 1 $\mathrm{kg}$ dengan lama pengeringan 14 jam, yaitu 4,8 yang artinya "sangat khas". Hal ini disebabkan karena aroma/bau khas bubuk cabai rawit yang diperoleh sangat kuat, sehingga lebih disukai oleh panelis.Sesuai dengan pernyataan Asni dan Suhiti (2017), mengemukakan cabai yang telah kering mempunyai bau dan rasa khas yang kuat.

Nilai rata-rata uji organoleptik pada aroma/bau khas terendah diperoleh pada perlakuan berat tumpukan $3 \mathrm{~kg}$ dengan lama pengeringan 14 jam yaitu 2,56, yang artinya "agak khas".Hal ini disebabkan karena aroma/bau khas khas bubuk cabai yang diperoleh tidak kuat, sehinggan tidak disukai oleh panelis.Cabai mengandung oleoresin yang menimbulkan aroma yang khas.Oleoresin adalah suatu produk yang mengandung resin, minyak-minyak esensial yang bersifat volatil dan bahan aktif lainnya yang diekstrak dengan pelarut non-aqueous seperti hidrokarbon (Furia, 1980).

Berdasarkan kualitas bubuk cabai menurut SNI 01-3389-1994 memiliki aroma/bau yang khas. Hal ini berarti bubuk cabai yang sesuai standar SNI melalui penilaian uji oganoleptik adalah dengan kombinasi perlakuan berat tumpukkan $1 \mathrm{~kg}$ dengan pengeringan menggunakan sinar matahari (kontrol) dengan rata-rata, yaitu 4,6 (sangat khas); berat tumpukkan $1 \mathrm{~kg}$ dengan lama pengeringan 14 jam yang dihasilkan dengan rata-rata, yaitu 4,8 (sangat khas); berat tumpukan $2 \mathrm{~kg}$ dengan pengeringan menggunakan sinar matahari (kontrol), yaitu 4,56 (sangat khas); berat 
tumpukan $2 \mathrm{~kg}$ dengan lama pengeringan18 jam, yaitu 4,68 (sangat khas); dan berat tumpukan $3 \mathrm{~kg}$ dengan pengeringan menggunakan sinar matahari (kontrol)yang dihasilkan dengan rata-rata, yaitu 4,08 (khas).

\section{KESIMPULAN}

Berdasarkan pada hasil pembahasan tersebut maka dapat disimpulkan, sebagai berikut.

1. Berat tumpukandan lama pengeringan memberikan pengaruh yang berbeda sangat nyata terhadap kualitas bubuk cabai rawit yang dihasilkan.

2. Berdasarkan hasil penelitian uji kimia, perlakuan berat tumpukan 22 jam dengan lama pengeringan 14 jam memiliki rendemen dan kadar air tertinggi.

3. Hasil penelitian uji organoleptik untuk rasa khas tertinggi adalah pada perlakuan berat tumpukan $2 \mathrm{~kg}$ dengan lama pengeringan 18 jam, sedangkan hasil uji organoleptik untuk aroma/bau khastertinggi adalah pada perlakuan berat tumpukan $1 \mathrm{~kg}$ dengan lama pengeringan 14 jam.

4. Perlakuan yang memenuhi syarat SNI013389-1994, yaitu pada berat tumpukan 1 $\mathrm{kg}$ dengan pengeringan sinar matahari, berat tumpukan $1 \mathrm{~kg}$ dengan lama pengeringan 14 jam, berat tumpukan 2 $\mathrm{kg}$ pengeringan sinar matahari, berat tumpukan $2 \mathrm{~kg}$ dengan lama pengeringan 18 jam, dan berat tumpukan $3 \mathrm{~kg}$ dengan pengeringan sinar matahari.

\section{DAFTAR PUSTAKA}

Anonima, 2011.Cabe Kering dan Cabe Bubuk. http://Bursaide.Com/lde/76/Cabe-
Kering-Dan-Cabe-Bubuk. Diakses 27 September 2015

Anonimb. 2012. Pengaruh Perlakuan Perendaman Air Panas (Blanching) dan TanpaPerlakuan (Non Blanching) Selama Proses Pengeringan terhadap PerubahanWarna Cabai. http://repository.unhas.ac.id/bitstrea m/handle/123456789/1535/SKRIPSI \%20LENGKAP.pdf?sequence=2. Diakses 16 November 2015.

Ardianto,Jamaluddin, Wijaya, Mohammad. 2016.Perubahan Kadar Air Ubi Kayu Selama Pengeringan Menggunakan Pengering Kabinet.Jurnal.Vol. 3 (2017):S112-S116.Fakultas Teknik. Universitas Negeri Makassar.

Asni, Nur., dan Suhiti, Kiki. 2017. Pengolahan Cabai Kering dan Tepung Cabai Berkualitas untuk Mengatasi Kelebihan Produksi dan Menunjang Agroindustri di Tingkat Petani Provinsi Jambi. Balai Pengkajian Teknologi Pertanian (BPTP) Jambi.

Dendang, Nataniel., Lahming, Rais, Muhammad. 2016.Jurnal. Pengaruh Lama Dan Suhu Pengeringan TerhadapMutu Bubuk CabaiMerah (Capsicum annuum L.) DenganMenggunakan Cabinet Dryer. Jurnal.Vol.2 (2016) : S30-39. Fakultas Teknik. Universitas Negeri Makassar.

Direktorat Pengolahan Hasil Pertanian Direktorat Jenderal Pengolahan dan Pemasaran Hasil Pertanian Departemen Pertanian. 2009. Standar Prosedur Operasional 
(SPO) Pengolahan Cabe. Jakarta:

Direktorat Pengolahan Hasil

Pertanian

Fitriani, S. 2008. Pengaruh Suhu dan Lama Pengeringan Terhadap Beberapa Mutu Manisan Belimbing Wuluh (Averhoabelimbi L.).Jurnal Sagu Edisi Maret Vol. 7 No. 1 Hal. 32-37. Laboratorium Pengolahan Hasil Pertanian. Fakultas Pertanian Universitas Riau.

Furia T. E. 1980. Hand Book of Food Additive Volume 1. $2^{\text {nd }}$ Edition. Florida:CRC Press Inc.Boca-Raton.

Hambali, E., Fatmawati, Permanik, R., 2005. Membuat Aneka Bumbu Instan Kering. Jakarta: Pebebar Swadaya.

Iswari, K., dan Srimaryanti. 2014. Pengaruh Giberlin dan Jenis Kemasan untuk Menekan Susut Cabai Kopay Selama Pengangkutan Jarak Jauh. Jurnal Pasca Panen. 11(2) 2014: 89-100.

Jusniati, Patang, Kadirman. 2017.Pembuatan Abon dari Jantung Pisang (Musa paradisiaca) dengan Penambahan Ikan Tongkol (Euthynnus affinis).Jurnal.Vol. 3 (2017) : 58-66. Fakultas Teknik. Universitas Negeri Makassar.

Kartasapoetra, G. 1994. Teknologi Penyuluhan Pertanian. Jakarta: Bumi Aksara.

Risnawati, Rais, Muhammad., Lahming. 2017.Analisis Kelayakan Teknis dan Ekonomis Pada Pengeringan BijiKenari (Canarium indicum L.)Dengan Menggunakan Alat Pengering
TipeCabinet.DryerJurnal.Vol.3 (2017) : S80-92. .Fakultas Teknik. Universitas Negeri Makassar.

Setiawatidan Winneke,Odilia. 2016. Cara Tepat Memakai Cabai Merah Kering. detik.com/food/read/2016. Diakses 29 Juli 2017.

Standar Nasional Indonesia. SNI 01-33891994. Tentang Persyaratan Mutu Cabai Kering

Suprapti dan Lies, M. 2003. Tepung Ubi Jalar Budidaya dan Analisis Usaha Tani. Yogyakarta: Kanisius.

Surianadan Neti. 2012. Cabai Sehat dan Berkasiat. Yogyakarta: Andi Offset.

Suyanti. 2007. Membuat Aneka Olahan Cabai. Jakarta: Penebar Swadaya.

Susinggih W., Sucipto, Lia M.S. 2015. Pengaruh Suhu dan Waktu Pengeringan terhadap Aktivitas Antioksidan pada Bubuk Kulit Manggis (Garcinia mangostana L.). Jurnal. Fakultas Teknologi Pertanian. Universitas Brawijaya. Malang.

RubiantydanKaseger,Berty.1985.Kimia

Pangan.

Makassar.BadanKerjaSamaPerguru anTinggiNegeri Indonesia BagianTimur.

Totok, Prasetyo., Kamaruddin, A., I. Made. K.D. 2008. Pengaruh Waktu Pengeringan dan Tempering Terhadap Mutu Beras pada Pengeringan Gabah Lapisan, Vol. 11, Nomor 1.

Taufik, Moh. 2013. Pengeringan Bahan Pangan: Jenis dan Faktor yang 
Mempengaruhi.www.moh.taufik.com

. Diakses 12 Februari 2017.

Yuarni, Desi., Kadirman, Jamaluddin. 2015.

Laju Perubahan Kadar Air, Kadar

Protein dan Uji

Organoleptik Ikan Lele Asin Menggunakan

Alat Pengering Kabinet (Cabinet

Dryer) dengan Suhu Terkontrol.

Jurnal. Vol.1 (2015) : 12-21.

Fakultas Teknik. Universitas Negeri

Makassar.

Yuliarti dan Dina Christina. 2001. Pengaruh

Suhu Pengeringan terhadap

Kandungan Capsaicin pada Cabai

merah Kariting (Capsicum annum

var, longun (DC.) Sendt. Tesis

Undergraduate. FMIPA Universitas

Dipenegoro. 